\title{
Park Planning and the Acquisition of Open Spaces: A Case Study
}

The need to preserve open spaces in urban areas is widely recognized. ${ }^{1}$ But varying geographic, social, economic, and political differences across so vast a country have led to diverse responses from the states to the problem of shrinking open spaces. ${ }^{2}$ Disagreement exists as to the best

1 Housing Act of 1961, tit. VII § 701(a), 42 U.S.C. \$ 1500; Housing and Urban Development Act of 1965, 42 U.S.C. \$ 1500; Housing Act of 1968, P.L. 50-448, 82 Stat. 476: CAL. Gov'T. CODE §§ 6950-54 (West 1966); ConN. GEN. StAT. ANN. § 7-131(a)-(k) and § 12107(a)-(e) (1969); IlL. ANn. STAT. ch. 571/2, \$§ 101-121 (Smith-Hurd Supp. 1969); MD. ANN. CodE art. 66C, § 357A (Supp. 1968); MAss. Gen. LAws ANN. ch. 40, § 8C (Supp. 1968); N.J. REv. STAT. § 13:8A-I to -18 (Supp. 1962); N.Y. MunIC. LAW § 247 (McKinney 1965); N.C. GEN. StaT. § 160-181.3 to -.10 (1964); PA. Stat. ANN. tit. 16, §§ 11,941-47 (1969), and tit. 72, § 3946.1-21 (1968); R.I. GEN. LAws ANN. § 45-36-1 to -2 (Supp. 1969); VA. CoDE ANN. § 10-151 to -158 (Supp. 1968). It is interesting to note that those states which have manifested their concern with dissipating open space in specific open space legislation, except for California and Illinois, form an unbroken line from North Carolina to Massachusetts. Only Delaware is missing from the chain of open space states.

See also Marky and-National Gapital Park and Planning Comm., Bi-County Open Space Planning, Past, Present \& Future 7 (Nov. 1968); The Washington Center for Metropolttan Studies, Open Spaces and Our Crties 7 (March 1961); O'Leary, Open Space FOR HUMAan NeEds, A Report to the Urban Renewal ADMinistration 6 (Aug. 1964); Northern Va. Regional Planning and Economic Dev. Comra., Open Space Easements, National Open Space Program Tech. Rept. No. 4, at v (Sept. 1965). In the Washington area,

Immediate needs for more recreation areas and open space are already evident.

Population expansion in the Region has been rapidly accelerating for more than

a decade, and suburban development is continually multiplying. Land costs are also increasing. The urgency of the situation is becoming more acute each year and efforts to protect the open space wedges must be intensified.

Levy, The Latw of Open Space in the National Captral Region, National Capital Open Space Program, Tech. Rept. No. 2, National Gapital Regional Planning Council vi (Sept. 1965).

Open space legislation represents an attempt, beginning this past decade, to deal with local problems of preservation of open land on a statewide basis. The legislation is designed to meet urban open space needs such as promoting outdoor recreation; guiding urban development; maintaining a readily available source of food and farm products close to metropolitan areas; and preserving flora, fauna, geological features, sites of historic or architectural interest, and scenic areas. To appreciate the full extent of state legislation concerning parks and recreation and of local action, one must also look to state and local laws in the related fields of conservation, outdoor recreation, parks, zoning, and other related subjects.

2 (1) GAL. Gov'r CoDE $\S 6951$ (West 1966) ("rapid growth and spread of urban development is encroaching upon, or eliminating, many open areas"), N.C. GEN. STAT. § 160-181.3 (1964) is similar; (2) N.J. REv. STAT. \& 13:8A-2(c) (Supp. 1962) ("expansion of population"), Pa. Stat. ANN. tit. 72, § 3946.2 (1968), and VA. Code ANN. § 10-151 (1968) are similar; (3) Conn. Gen. Stat. ANn. \$ 12-107(a) (1969) (forced conversion of open land to developed 
methods-in terms of speed, expense, and effectiveness of control over the land-to be used to preserve open spaces. Park and city planners may choose from among a multitude of acquisition and regulatory techniques. ${ }^{3}$

Ultimately the planners' choices of how to preserve urban open space are limited by the acquisition and regulatory methods which a local acquiring agency may use, which in turn are limited by the agency's grant of power from the legislature. This comment will focus on the use of five possible techniques for acquiring land for public park or recreational use: purchase, transfer, condemnation, donation, and subdivision dedication. Specifically, it will investigate whether local open space acquisition programs in the Bi-county region of Montgomery and Prince George's Counties, Maryland, conform to existing legislation, how effective those programs are in preserving open spaces, and what new legislation may be necessary to realize the planners' goals.

The Bi-county region, adjoining Washington, D. G., on all but its southwestern boundary, contains one million people within a one thousand square mile area. ${ }^{4}$ Except for rapid urbanization along the Washington fringe, the region is largely devoted to farming. The value of using the Bi-county region as a case study of park acquisition techniques lies in its having open space problems typical of urban areas, yet unique to its location on the fringe of the national Capital. Like

uses due to market value tax assessment making minimum use non-profitable); (4) VA. CODE ANN. § 10-151 (1968) ("Critical problems of service and finance for the State and local governments"). An additional explanation, not stated in the statutes, is the rising price of land. Land costs rose an average of more than $15 \%$ a year in the Bi-county region and $10 \%$ over the entire state.

3 See Note, Open Space Legislation: Suggestions for a Model Act, 2 GA. L. REv. 294, 296 (1968).

\begin{tabular}{|c|c|c|c|c|c|}
\hline Mo & $\begin{array}{l}\text { URBANIZ } \\
\text { ERY AND }\end{array}$ & $\begin{array}{l}\text { ID RuRAt } \\
\text { IE GEORG }\end{array}$ & $\begin{array}{l}\text { ULATION* } \\
\text { OUNTIES, }\end{array}$ & RYLAND & \\
\hline & 19501 & 19601 & 19682 & 19852 & $\begin{array}{l}\text { Land Area } \\
\text { (Sq. Mriles) }\end{array}$ \\
\hline Montgomery County & & & & & \\
\hline $\begin{array}{c}\text { Total Population } \\
\text { Urbanized Area } \\
\text { Rural Area }\end{array}$ & $\begin{array}{r}164,400 \\
117,500 \\
46,900\end{array}$ & $\begin{array}{r}340,900 \\
289,500 \\
51,400\end{array}$ & $\begin{array}{r}494,000 \\
433,500 \\
60,500\end{array}$ & $\begin{array}{r}830,000 \\
761,100 \\
68,900\end{array}$ & 494 \\
\hline Prince George's Cou & & & & & \\
\hline $\begin{array}{l}\text { Total Population } \\
\text { Urbanized Area }\end{array}$ & $\begin{array}{l}194,200 \\
135,900\end{array}$ & $\begin{array}{l}357,400 \\
289,400\end{array}$ & $\begin{array}{l}615,500 \\
541,300\end{array}$ & $\begin{array}{r}1,039,400 \\
960,000\end{array}$ & 488 \\
\hline Rural Area & 58,300 & 68,000 & 74,200 & 79,400 & \\
\hline
\end{tabular}

* The Maryland-National Capital Park and Planning Commission, Bi-county Planning Services, Research Division.

Sources:

1 U.S. Bureau of the Census, Census of Population, 1950, 1960.

2 Estimates and Projections by the Research Division, Maryland-National Capital Park and Planning Commission. 
all urban areas, the Bi-county region must provide for expanding residential, business, and industrial land needs, while at the same time make provisions to save open space for park and recreation needs. ${ }^{5}$ Because other urban areas have similar open space needs, a study of the Bi-county region will be instructive to those seeking similar optimal solutions to their own needs within the framework of different local land laws.

The Bi-county region has a unique relationship with the federal government, because of the area's proximity to Washington and because of the federal government's desire that the open space programs of the Capital and the surrounding region be compatible. On occasion this has led the federal government to cancel or threaten to cancel open space acquisition grants when it opposed local administrative land use decisions. ${ }^{6}$ Consequently, while over time the Bi-county region has been one of the largest single recipients in the nation of federal grants for open space acquisition, for the last few years it has looked to the county governments rather than to the federal government for most of its funds. ${ }^{7}$

The Maryland-National Capital Park and Planning Commission administers the open space program in the Bi-county region. The Commission is a permanent, independent planning and land acquisition agency serving the Bi-county region. Internally, it is broken down into five integrated ${ }^{8}$ departments: legal, parks, planning, public relations, and park maintenance. While regular employees make the Com-

5 It should be pointed out that not everyone approves of a program to expand the amount of park facilities in the Bi-county region. Opposition to increased park acquisition and development comes primarily from two sources: those who feel that land should be devoted to other public uses (highway advocates are a good example) and those who do not want money spent for parks which will be used by nonresidents. Interview with Harry Lerch, General Counsel for the Maryland-National Capital Park and Planning Commission, in Silver Spring, Md., December 30, 1968.

6 This occurred in 1966 when the lame duck Montgomery County Zoning Board, as a farewell gesture, rezoned 2,000 acres of low density residential land for commercial and high density residential development. The Department of Housing and Urban Development promptly held up approval of an open space grant application, the Agriculture Department withdrew a grant of money, and the Secretary of the Interior had some unflattering comments to make about the outgoing zoning board. The new board undid its predecessor's last minute rezoning, after much local pressure as well as the threat of withdrawal of federal assistance. After this experience some commentators predicted a more vigorous overseeing role for the federal government in suburban Washington land use affairs. W.H. WHYTE, THE LAST LANDSGAPE 46 (1968).

7 Urban areas farther removed from governmental scrutiny, however, continue to look to Washington for increasing amounts of land acquisition funds. Under the Housing and Urban Development Act of 1968, 82 Stat. 534, $\$ 460$ million was authorized for matching grants to state and local governments for the acquisition of open spaces.

8 There are scheduled staff meetings where the heads of each department discuss the problems and suggestions of their departments. 
mission their career, the ten commissioners who head up the Commission are appointed by the governing body of each county. ${ }^{9}$ Commissioners appointed from each county also serve on that county's Planning Board, which administers purely local (as opposed to the Commission's regional) planning and zoning functions..$^{10}$

The Commission has been a widely copied model of regional open space planning and acquisition expertise since its inception in 1927.11 It continues to develop new open space preservation techniques. ${ }^{12}$

\section{A Gase Study of the Bi-county Region}

\section{A. Anticipated Open Space Needs}

In a large area such as the Bi-county region it appears that there should be no lack of open land. Only one-fifth of the land is developed, and by the year 2000 approximately one-half of the land will remain open. ${ }^{13}$ These figures accurately reflect current land use, but for several reasons they are deceptive as an indicator of present and future conditions. First, figures representing the total open space acreage of a region mask the fact that much of the land is in small parcels, on steep slopes, or otherwise unfit for recreational use. Additionally, the largest expanses of open land, such as farmland, lie farthest from Washington; in the areas of highest population concentration, open spaces are often insufficient. ${ }^{14}$ Second, what open space

9 Five are appointed from each county. Laws of Md., ch. 780 \& (1959), ch. 433 (1965), ch. 720 (1967), amending Montgomery County Code and Code of Public Local Laws of Prince George's County.

10 Laws of Md., ch. 780, \& 66 (1959), ch. 814, § 66(b) (1961), amending MONTGOMERY County Code and Code of Public Local Laws of Prunce George's County.

11 The Commission was one of the first agencies in the country to apply for and receive federal open space assistance funds under the Housing Act of 1961. Prince George's County was the first county in the nation to provide landowners with a $50 \%$ tax credit for perpetual scenic easement donations. The Bi-county was a recipient of funds under the Capper-Cramton Act, 46 Stat. 482 (1930), the first major federal legislation appropriating money to be spent in the Washington area to preserve open land, particularly to acquire stream valley parks.

12 In November 1968, the Commission presented a public symposium on problems of open space preservation in urban areas. In addition to the acquisition techniques the Commission currently employs, which are discussed in this comment, the Commission presented more than 40 new acquisition and regulatory open space preservation methods with the expectation of implementing the most useful of them in the future.

13 Maryland-National Gapttal Park and Planning Comm., ON Wedges and Corridors, A General Plan for the Maryland-Washington Regtonal District in Montgomery and Prince George's Counties 8 (Jan. 1964); Martland-National Gapital Park and Planning Comar., Preliminary General Plan for the Maryland-Washington ReGIONAL Districr 86 (Nov. 1956). It was then estimated that $77 \%$ of the Bi-county region was vacant, roodland, or agricultural.

14 Maryland-National Capital Park and Planning Comm., Preliminary General Plan for the Maryland-Washington Regional District 86 (Nov. 1956). 
remains in the suburbs must serve not only Maryland's growing population, but also the already land-deprived residents of Washington, and to some extent, visitors to the Capital. ${ }^{15}$ Third, increases in leisure time and income will provide residents and others with more opportunity to make use of area recreational facilities. ${ }^{16}$ Fourth, as the development value ${ }^{17}$ of land soars, it becomes decreasingly profitable to leave it undeveloped (or in marginal uses, such as farming). The value of land in Montgomery and Prince George's Counties has risen by at least fifteen per cent per year up until the last two years, with the cost of an acre of land ranging from a few hundred to more than twenty-five thousand dollars. ${ }^{18}$ Finally, land speculators have purchased much land near Washington, allowing farmers to remain as tenants to insure a preferential tax treatment ${ }^{19}$ which they will give up as soon as it is less valuable than development. ${ }^{20}$

15 Id. at 90; National Capital Park and Planning Comm., Washington Present and Future, a General Summary of the Comprehensive Plan for the National Capital and its Environs 34 (Apr. 1950); Northern Va. Regional Planning and Economic Dev. Comm., action for Open Space, Nationad Capital Open Space Program, PlanNING REPT. No. 1, 2 (Nov. 1965).

16 The 1960 median family incomes for Montgomery County $(\$ 9,317)$ and Prince George's County $(\$ 7,471)$ averaged together, are higher than those for any other similar jurisdictions in the metropolitan area. Acrion FOR OPEN SPACE, supra note 15, at 13.

17 Development value is based on the highest use to which the land can be put in conformity with local land use laws. This is sometimes referred to as a development right, the landowner's right to build-houses, apartments, warehouses, or whateveron his land. Approximately $90 \%$ of the land value in the urban areas of the Bi-county lies in the land's development potential. Of course, if not all of the development rights are purchased, the cost will be proportionately less. Thus, the cost of a scenic easement will vary with the amount of development which is restricted.

18 For the last two years there has been almost no rise in land values, due to slack demand in a tight money market. Prices have not fallen, however.

19 Mo. Code AnN. art 81, § 19(b) (1965).

20 Open space farmland, so long as it remains in agricultural use, without regard to who owns the land, is taxed at a rate based on its use as a farm rather than its potential market value as subdivided land. Supervisor of Assessments for Montgomery County v. Alsop, 232 Md. 188, 192 A.2d 484 (1963).

The Maryland Legislature, in Senate Bill (1968) would have disallowed the preference when land was either subdivided, rezoned, or sold for an amount greater than seven times its assessment as farmland. (The Governor vetoed this Bill. A vote to overturn the veto failed on the first day of the 1969 Session, although two-thirds of the Senate and a majority of the House voted against upholding the veto. One legislator defended his vote supporting the veto with the observation, "a farm is a farm is a farm.") The 1968 Session also passed a law granting Montgomery County power to impose a transfer tax of up to $6 \%$ of the sale price of land assessed as farmland. The Montgomery County Council enacted an ordinance implementing this, but delayed its enforcement until July 1969. It is submitted that both of these measures will retard the conversion of open farm land into developed uses, but their benefits will not offset the financial advantages which the present law gives to speculators. Interview with State Secretary of State Blair Lee III, formerly Maryland State Senator from Montgomery County, in Silver Spring, Md., Dec. 24, 1968. See text at notes 86-89 infra. 
The inevitable-and unpleasant-conclusion is that open land for recreational use may not be avaliable at the time and for the price at which local agencies will be able to acquire it. This is especially true in the Bi-county region where the park acquisition program emphasizes large regional and stream valley parks.

B. Open Space Acquisition Techniques in the Bi-county Region: Methods Employed by the Maryland-National Capital Park and Planning Commission

The Commission uses five techniques to acquire land in the $\mathrm{Bi}$ county area: ${ }^{21}$

1. Purchase
A. Fee simple
B. Less than fee simple (scenic easements)

2. Transfer

3. Condemnation
A. Fee simple
B. Less than fee simple (scenic easements)

4. Donation
A. Fee simple
B. Less than fee simple (scenic easements)

5. Dedication in subdivisions.

1. Purchase 2 - (A) Fee simple. The Commission's open space acquisition program emphasizes acquisition of the fee simple. As of October 1968, the Commission had purchased 21,646 acres of park land, with another 2,174 acres under option agreement contracts ${ }^{23}$ and 2,144 acres under contract awaiting final settlement, for a total of 25,964 open space acres. ${ }^{24}$ Most of the land lies within Montgomery County. ${ }^{25}$

\footnotetext{
21 "Any county or city, the Maryland-National Capital Park and Planning Commission and the State Department of Forests and Parks, may acquire, by purchase, gift, grant, bequest, devise, or lease, the fee or any lesser interest" in real property for the preservation of open space land in Maryland. Mo. CoDE ANN. art. 66C, § 357A (1968). Supplementing this general enabling statute is the specific provision that the Commission may acquire "property ... for parks ... by means of donations, purchases, or condemnation." LAws of Md., ch. 780, § 26(a) (1959) amending Montgomery CounTy CodE and Code of Public local Laws of Prince George's County. See also Laws of Md., ch. 780, §§ 26(b), 29 (1959), and ch. 485 (1961), amending MONTGOMERY COUNTY CODE and Code of Public local Laws of Prince George's County.

22 Purchase in this section refers solely to market place acquisitions. The Commission as purchaser operates as any private buyer, negotiating with the seller for the best price without resort to condemnation proceedings.

23 See text at note 32 infra.

24 Interview with Joseph Downs, Principal Park Planner of the Maryland-National Capital Park and Planning Commission, in Silver Spring, Md., January 2, 1969.
} 
The projected goal for the year 2000 is 29,300 acres for Montgomery County and 28,500 for Prince George's County. ${ }^{26}$

Of the several available methods of purchasing the fee simple, the Commission has most extensively utilized outright, immediate purchase. This puts a strain on budget flexibility. The Commission has a limited amount of funds for acquisition, so that the higher the proportion of the purchase price it must pay initially, the fewer parcels of land it will be able to acquire. For this reason the Commission plans to utilize outright purchase only when there is an immediate need for control, use, and access to the land by the public. ${ }^{27}$ When land is bought in advance of park needs, the Commission has been able either to pay less than the full price initially or to recoup a portion of the purchase price in rentals on the property while it is unneeded for park use. By paying less initially the Commission greatly expands its purchasing ability.

Purchase and lease-back ${ }^{28}$ and purchase with a lifetime estate are two money-saving methods. The lease-back plan, like outright purchase, necessitates an outlay of the market price of the fee. ${ }^{29}$ The purchase

25 As of November, 1968-

\begin{tabular}{lcc} 
& Montgomery County & Prince George's County \\
\hline Purchased & 14,618 acres & 6,928 acres \\
Option-Contract & 1,936 acres & 438 acres \\
Contract Awaiting Settlement & 84 acres & 1,060 acres \\
\hline
\end{tabular}

Until this year, the Prince George's County branch of the Commission employed no one full time to oversee its land acquisition program. With that office now filled. Prince George's County has moved quickly to catch up with Montgomery County by increasing its parkland purchases by $331 / 3 \%$ between June and October 1968. The Washington Post, Nov. 29, 1968, at G-1.

As of July 1965, the Commission owned approximately $55 \%$ of the parkland in the Bi-county area (30\% of Prince George's County's parks and $75 \%$ of Montgomery County's parks). This contrasts markedly with Northern Virginia and the District of Columbia where the federal government owns $70 \%$ and $90 \%$, respectively, of the public open space land. The percentage figures of Commission ownership are currently even higher because it has acquired a great deal of land relative to state and federal agencies since 1965.

26 Interview with Joseph Downs, Principal Park Planner of the Maryland-National Capital Park and Planning Commission, in Silver Spring, Md., January 2, 1969.

27 Bi-County Open Space Planning, supra note 1 , at 61.

28 The Commission has the power to lease lands acquired but presently unneeded for public parks to any individual or corporation for a term not exceeding twenty years but renewable for additional ten year terms if the purpose for which the land is leased is not inconsistent with its use as a park. Laws of Md., ch. $780 \$ \S 35-6$ (1959), ch. 611 (1961), amending Montcomery County Code and Code of Public Local Laws of Prince GEORGE'S COUNTY.

29 The Commission has found that it is easier to raise money through public bond issues rather than mortgages on parkland. This is probably because, until recently, the tax-free return on municipal bonds made them an attractive investment for individuals in high tax brackets. 
price of the land encumbered with a lifetime estate, however, is the market value of the fee less the value of the retained life estate, but the Commission infrequently receives rental income from such property. Seller and purchaser benefit from both techniques; both remove the land from the tax rolls (since the Commission owns the fee), both will prohibit the lessor or life tenant from significantly modifying his property (removing timber, constructing buildings, and the like), and both allow the Commission to escape maintenance costs in the interim.

Because neither technique automatically grants public access to the land until the lease has run out or the life estate terminated, lease-back and purchase with a life estate are best employed when there is no immediate need for the land..$^{30}$ Neither purchases with lease-back nor those subject to life estates account for a significant amount of Commission acquisition. Currently only about ten per cent of the acquisitions in Montgomery County, and none in Prince George's County, are leased back to the original seller or to others. There are five life estates on future park lands in Montgomery County. ${ }^{31}$

A third way to acquire land at current prices for future needs is the option-agreement plan. ${ }^{32}$ After negotiations with the owner, the land is marked off into a number of segments equal to the amount of years (usually ten) the option is to run. Each annual payment perpetuates the option to buy the next segment at the original price until the entire parcel is acquired.

Installment purchases are advantageous to both buyer and seller. The Commission, by expending annually less than the total cost for a piece of land, is simultaneously able to acquire options on more land than it would otherwise be able to contract for. The Commission realizes large-scale savings, given the ever-increasing cost of land, by paying subsequent installments at property values established at the contract date. During the option period, the land will remain substantially unaltered by the seller's agreement "not to use the property for harvesting or sale of timber or sod, nor put the property to any use that would be inconsistent with the future use of the land for park and recreation purposes." ${ }^{33}$ Unless otherwise specified in the contract, the land will be placed in reserve and removed from real property tax rolls. ${ }^{34}$ One key to the success of land installment negotia-

30 While the time when the Commission will be able to control the land is certain with the lease-back, there is no certainty when the life tenancy might end. This could present difficult problems in park planning.

31 See generally BI-County OpEN SPACE PzAnning, supra note 1 , at 63-64.

$32 \mathrm{Id}$. at $62-63$.

33 Maryland-National Capital Park and Planning Commission Land Installment Purchase Contract.

34 Md. Code ANN. art. 81, § 12E(h) (Supp. 1968). 
tions can be how high the seller's income tax bracket is and how desirous he may be of receiving favorable capital gains treatment on the profit from his sale.

Land option contracts receive top priority from the Commission. There are presently twenty installment contracts in Montgomery County on which the Commission pays $\$ 1.8$ million annually. ${ }^{35}$ Prince George's County is just beginning to experiment with option purchases. In general, the option purchase is best employed in rural areas where the pressure to develop is slight, so that farmers are willing to accept future installments at a price established on present values. Moreover, in rural areas the Commission has no immediate need of the land, and it does not mind deferring complete access for several years. ${ }^{36}$

Another method of acquiring the fee simple is by purchase at a tax sale. After a landowner has been delinquent for one year on his real estate taxes, the assessment office, before offering the land for public sale, allows public agencies to buy a tax certificate for the amount of the delinquency. If the taxes remain unpaid for another year, the public agency (the Commission in this instance), may purchase it through private negotiation with the owner or at public sale, usually for a price below its market value. Public agencies gain only a slight advantage through the use of tax certificates; by purchasing them they are by no means assured of acquiring the land, even if the original owner does not redeem his land by paying the back taxes. ${ }^{37}$ Tax delinquencies are published in the local newspapers; any speculator may compete with the Commission by offering to purchase the land with its encumbrances from the owner during the interim year in which the Commission holds the tax certificate, and the Commission may in some cases have to compete with the public at auction. The sole

35 Interview with Joseph Downs, Principal Park Planner of the Maryland-National Capital Park and Planning Commission, in Silver Spring, Md., January 2, 1969.

36 Installment purchase has occasionally worked well in highly developed sections of the Bi-county area. For example, in 1961 the Commission took an option to purchase 72.5 acres over a ten year period on land situated in a residential section of Montgomery County about 12 miles from Washington. The land, valued at $\$ 4,500$ per acre when the parties contracted, is today worth approximately $\$ 18,500$ per acre. In this case, the option agreement technique saved the Commission more than $\$ 500,000$. The fact that the land would be preserved as a park almost certainly influenced the seller in accepting a loss.

37 At any time during the year after the public agency buys the tax certificate, and for a year and a day following a tax sale purchase, the owner may pay off his back taxes and regain clear title. Stewart v. Wheatley, $182 \mathrm{Md}$. 455, 35 A.2d 104 (1943). In Prince George's County, a tax sale purchaser may be barred from asserting his title against an owner who remains in adverse possession of the property for seven years after ratification of the tax sale, MD. Cone ANN. art. 57, \& 15 (1957). 
advantage in holding a tax certificate lies in forcing other prospective buyers to take the initiative.

Tax delinquent purchases are infrequent. ${ }^{38}$ Land values are so high in the Bi-county region ${ }^{39}$ that landowners rarely are unable to refinance their land to secure funds for taxes. Those parcels of land which are offered to the Commission as tax delinquent are usually either too small for park use or outside planned park areas.

A final method whereby the Montgomery County Council, but not the Commission, can defray land acquisition costs is by having the county government purchase and resell excess lands surrounding new parks.

Under the Public Facility Area Development Law of 1968,40 the Montgomery County Council may acquire ${ }^{41}$ excess lands surrounding a public facility (including parks), hold the land for a "suitable time," and then dispose of it to private individuals or public corporation purchasers for development according to a public facility area plan. ${ }^{42}$ The sale or rental of the land must be at fair market value. Although no excess lands have as yet been purchased under this statute, one may speculate that the law will affect open space acquisition in two ways. ${ }^{43}$ First, Montgomery County may purchase surrounding land at the time it acquires park areas and benefit, at the time it disposes of those lands, from the increase in their value due to the creation of the park. The County government, in effect, will become a land speculator with a guaranteed profit which can be applied to other open space projects. Second, because the use of the excess land must conform to an area development plan, the statute will help to insure that the land will remain open or in some compatible use. For example, the County could resell excess lands while retaining a scenic easement. There would be little or no cost to the County because the normal increase in the value of the excess land

\footnotetext{
38 See generally BI-County Open SPAge Planning, supra note 1, at 67-68. 39 See text at note 18 supra.

40 Laws of Md., ch. 607 (1968) amending Montgomery County Code.

41 The statute does not allow acquisition of excess land by condemnation.

42 Lerch v. Maryland Port Authority, 240 Md. 438, 214 A.2d 761 (1965).

43 One of the main purposes of the statute is to secure "the orderly, planned development of land adjacent to ... public facilities." This same goal could be attempted through zoning; however, the fact that the legislature preferred a contract between the county and private developer restricting land use would appear to give support to the view that zoning for open spaces is not the best way to keep land from being developed.

The statute allows the county to acquire and sell excess lands only when the county also purchases the actual site of the public facility. The statute should be amended to allow the county to purchase excess lands surrounding a park acquired by the Commission as well as by the county.
} 
(due to its proximity to a public park) would offset the decreased price the land, encumbered with a scenic easement, would bring.

We have seen that the Commission has emphasized outright purchase of the fee. ${ }^{44}$ Because this method requires an immediate outlay of the total market price and results in a limited amount of land purchases, the Commission has recently been employing other methods of acquisition designed to decrease or spread out the cost of acquisition without a proportionate increase in annual expenditures. The result should be a marked increase in parkland acquisition.

1. Purchase-(B) Less than Fee Simple (scenic easements). ${ }^{45}$

2. Transfer. The operations of the State Roads Commission and other public agencies, often a threat to the existence of parks, ${ }^{46}$ can sometimes aid the park acquisition program. With the consent of the State Roads Commission, or another government agency, the Commission may negotiate to purchase property which that agency owns but does not need. The cost is the original purchase price plus interest, usually a substantial saving relative to the land's present market value. However, because the land was originally purchased for a non-park use, such as a highway, it is often topographically unusable or too far removed from population centers to serve their recreational needs. ${ }^{47}$

3. Condemnation-(A) Fee Simple. The state's power to condemn land within its boundaries for public uses with just compensation is inherent. ${ }^{48}$ The legislature has delegated this power to the Commission for the stated purpose of acquiring parkland. ${ }^{49}$ Despite this clear-cut authority to acquire land by eminent domain, the Commission rarely uses it as a tool to acquire parkland. Instead, Commission officials prefer to negotiate using condemnation as a last resort. ${ }^{50}$ In

44 See text at note 22 supra.

45 This section is treated in combination with section $4(\mathrm{~B})$-Donation-Less than Fee Simple (scenic easements).

46 See text at note 64 infra.

47 Bi-County Open Space Planning, supra note 1 , at 68-69.

48 Moale v. Mayor of Baltimore, 5 Md. 314, 61 A.D. 276 (1854); Riden v. Philadelphia, B. \& W.R. Co., 182 Md. 336, 35 A.2d 99 (1944).

49 Laws of Md., ch. 780, § 30 (1959) amending Montgomery County Code and Code of Public Local Laws of Prince George's County. Taking for a public park, with adequate compensation to the landowner, has survived a recent court challenge. Kline $v$. Rockville, 245 Md. 625, 227 A.2d 217 (1967). The case held that the condemning agency's power to choose the land to be condemned was absolute and that on appeal, the appellant could challenge only (1) whether there was any necessity whatsoever for the taking or (2) whether the decision of the agency was so oppressive, arbitrary, or unreasonable as to suggest bad faith.

50 Interview with Joseph Downs, Principal Park Planner of the Maryland-National Capital Park and Planning Commission, in Silver Spring, Md.; January 2, 1969. 
the past ten years, seven condemnation proceedings were initiated, only three of which ended in a forced sale to the Commission. ${ }^{51}$ The number is small because the Commission has found condemnation proceedings and delays to be too costly in the long run. The Commission needs public support for its parkland acquisition program in order to continue to receive additional funds from the Montgomery and Prince George's County governments. Condemnation can be a public relations nightmare.

Disuse of the Commission's condemnation power, however, is no argument for the removal of that power. The threat of condemnation may be as effective as the actual initiation of condemnation proceedings in influencing a landowner to sell. ${ }^{52}$ The Commission does not publicize its no-condemnation policy; as far as local landowners are concerned the Commission has both the ability and willingness to take their land. ${ }^{53}$

3. Condemnation-(B) Less than Fee Simple (scenic easements). The Commission's authority to condemn land expressly includes the power to take an easement on the land. ${ }^{54}$ As a matter of logic it is debatable whether condemnation of a scenic easement, unlike condemnation of the fee for a public park, would satisfy the due process requirement of a "public purpose" for a taking, because with ease-

51 The condemnation proceedings occurred prior to the Commission's current reluctance to condemn.

62 W.H. Whyte, The LAST LANDSCAPE 54 (1968). Using the possibility of condemnation as a means to influence a sale in private negotiations would probably not result in the diminished respect which flows from a court battle because of the absence of publicity and general informality surrounding private negotiations. However, long disuse of its condemnation power would imply an unwillingness to condemn; if landowners recognized this, it would eliminate the threat of condemnation as an effective bargaining point.

53 The Commission should be aware of the threat to its power from proposed state laws which might remove its power to condemn. For example, Senate Bill 313, a comprehensive open space bill which failed to pass the 1968 Maryland General Assembly, included an amendment which would have specifically removed the power of public bodies to condemn land for open space use. There was no provision that political bodies currently exercising this power would retain it. The significance of Senate Bill 313 for purposes of the present discussion lies in the fact that the denial of authority to condemn was an amendment to an otherwise acceptable bill. Most open space legislation in Maryland runs a great risk of being saddled with this type of amendment by a minority of legislators who actively oppose the use of condemnation for parks. Similar amendments will no doubt recur, probably appended to bills which, but for this provision, should be enacted. Rather than attempt to defeat the whole of any park acquisition legislation the Commission will seek to have inserted in bills a clause stating that no part of the Bill shall limit existing authority of local bodies to condemn for public parks.

54 Laws of Md., ch. $780 \$ 30$ (1959) amending MONTGOMERY COUNTy CODE and CODE of Public local Laws of Prince George's County. New Jersey grants similar power to local governments, N.J. STAT. ANN. § 40:32-2 (1967). 
ments the public enjoyed no access to the land and because the preservation of scenic beauty was not considered a public purpose. In the mid-1950's, both issues were resolved. In Herzinger $\%$. City of Baltimore, ${ }^{55}$ the Maryland Court of Appeals, in a case concerning governmental acquisition of land for slum clearance and redevelopment, held that a benefit may be conferred on the public even where the public has no right of access to the condemned land. The court stated, "the fact that after the taking the property may be put into private hands does not destroy the public character of the taking insofar as that taking may accomplish a proper public benefit." 56 That the fee was taken in that case rather than an easement should not prevent the application of similar principles to easement condemnations.

One year after Herzinger the second issue was settled when the Supreme Court, in the case of Berman $v$. Parker, ${ }^{57}$ came very close to holding that condemnation for aesthetic purposes alone met the public purpose test. In an often cited paragraph, the court stated:

The concept of the public welfare is broad and inclusive .... The values it represents are spiritual as well as physical, aesthetic as well as monetary. It is within the power of the legislature to determine that the community should be beautiful as well as healthy, spacious as well as clean, wellbalanced as well as carefully patrolled. ${ }^{58}$

Berman $v$. Parker has received overwhelming acceptance and the trend would appear to follow Berman's approval of preservation of scenic values as a public purpose. ${ }^{59}$

55203 Md. 49, 98 A.2d 87 (1953). In Master Royalties Corp. v. Mayor and City Council of Baltimore, $235 \mathrm{Md} .74,200$ A.2d 652 (1963), the court interpreted Article 11B of the constitution (relating to urban renewal in and by the City of Baltimore) to embody a public purpose if the use of the land benefitted the public even though the use was not $b y$ the public. In Lerch v. Maryland Port Authority, 240 Md. 438, 214 A.2d 761 (1965), the court held that the development and construction of an International Trade Center by the Maryland Port Authority encompassed a public purpose despite a plan to lease portions of the Center to tenants wholly unrelated to the maritime industry for the production of incidental revenues. See also Frostburg v. Jenkins, 215 Md. 9, 136 A.2d 852 (1957), where the court held constitutional a state enabling act authorizing the city of Frostburg to spend public funds to purchase a site and to contribute to the cost of constructing a building to be used by a privately owned manufacturing company.

56203 Md. 49, 60, 98 A.2d 87, 93 (1953).

57348 U.S. 26 (1954). Cited with approval in Feldstein v. Kammauf, 209 Md. 479, 487, 121 A.2d 716, 719 (1955).

58348 U.S. 26, 33 (1954).

59 See State ex rel. Saveland Holding Co. v. Wieland, 269 Wis. 262, 271, 69 N.W.2d 217, 222 (1955) (zoning ordinance "grounded largely on aesthetic considerations" satisfics public purpose requirements, the court citing Berman v. Parker). 
The Commission's power to condemn scenic easements has not been challenged; its authority would probably be upheld in light of the cases discussed above and the frequent judicial approval of condemnation of other development rights. ${ }^{60}$ The Commission has manifested no inclination to use this method, preferring instead to acquire a fee simple interest. ${ }^{61}$ This probably reflects both the Commission's desire not to use its condemnation power, ${ }^{62}$ and the high value of development rights, which approximate the cost of the fee in the Bi-county region. ${ }^{63}$

4. Donation-(A) Fee Simple. Acquisition of parks through private donation is essentially a public relations task. It involves informing landowners of potential tax savings and, sometimes even more important, describing the personal satisfaction of creating a memorial park. Perhaps the biggest public relations job in encouraging donations is to convince the donor that the Commission does not fritter away its parkland in transfers to other agencies for non-park use. In areas where parks have been lost to state roads, it is almost a certainty that this has had an adverse effect on potential park donations. ${ }^{64}$

The Commission must be careful to point out that no public park is more secure than one privately donated. An individual may restrict the use of his gift to public park use in perpetuity without voiding a gratuitous transfer. ${ }^{65}$

Unfortunately, only a few donors have been found in Montgomery County. ${ }^{66}$ Prince George's County has received many more donations,

60 United States v. Avigation Easement, 140 F. Supp. 289 (D. Ala. 1956); United States v. 72.35 Acres of Land, 150 F. Supp. 271 (E.D. N.Y. 1957); United States v. 765.56 Acres of Land, 174 F. Supp. 1 (E.D. N.Y. 1959).

61 The federal government has used it. In 1965 it condemned an easement on a 47 acre tract along the Potomac River in Fairfax City, Virginia to the consternation of the landowners, who had just succeeded in having the land rezoned for apartments.

62. See text at notes 48-53 supra.

63 See text at note 14 supra.

64 See Weissburg, Legal Recognition of the Public Interest in Open Space, Regionar Parks ANd Open Space: Selected PApers 28 Bureau of Public Administration, U. of Cal. at Berkeley (June 1961); A. Dunham, Preservation of Open Space Areas, A Study of THE NON-GOVERNMENTAL ROLE 2 (1966).

In Minnesota v. Christopher, currently before the Minnesota Court of Appeals, the Park Commission took the Highway Department to court to prevent the latter from running a highway through Minihaha Park. In the Bi-county region this has not yet become a problem, though the danger that it will always exists. Cf. District of Columbia Fed'n of Civic Ass'ns; Inc. v. Airis, 275 F. Supp. 540 (1967) rev'd 391 F.2d 478, 483 (1968) ("state laws regulating the planning and building of highways were not set aside by the Federal-Aid Highway Acts").

65 The question of what further restrictions on gratuitous transfers of land will operate to void the gift involves property law considerations beyond the scope of this comment.

66 For example, Violet Blair Janin, a niece of Montgomery Blair, who was Lincoln's 
probably because there are no subdivision dedication requirements ${ }^{67}$ there, (other than compliance with Master Plans), but developers have found it expedient to donate land anyway, ${ }^{68}$ since a community park raises the value of surrounding land and helps satisfy maximum density requirements, yet creates no tax or maintenance burden on the developer.

4. Donation-(B) Less than the Fee Simple (scenic easements). The Commission is authorized to purchase, or accept donations of, scenic easements to preserve open spaces. ${ }^{69}$

In order to "encourage and assist the preservation of open space," state law enables Montgomery and Prince George's Counties to reduce real estate tax assessments up to 100 per cent on land (1) which is determined to be open space by the Commission, and (2) for which the owner has conveyed or assigned the Commission "an easement or interest in the land which limits the use thereof in such manner as to preserve its natural character in perpetuity."70

In January 1966, pursuant to this authorization, Prince George's County became the first county in the nation to adopt a scenic easement tax credit ordinance. Under the Prince George's law, a flat fifty per cent tax credit may be granted if the Commission determines that the donated land is an open area of at least five acres. In return for the tax credit, the landowner agrees not to erect billboards, public utility installations, or buildings, and not to remove trees larger than a standard size, dump ashes or trash, or conduct mining or industrial

Postmaster General and an extensive landholder in Maryland, devised land to the Commission for use as a public park located at the boundary between Washington and Montgomery County. Illustrative of some of the conditions which a devisee may impose on his gift, Violet Blair Janin provided in her will that (l) the park be established in memory of and named after her brother, Jesup Blair, (2) provision be made to perpetually maintain the property as a public park, and (3) all existing trees be preserved if possible with the request that any which are destroyed or die be replaced. These provisions are restated in the laws and regulations of the Commission, and the Com. mission is authorized to carry out the directions of the will. No court battle has been necessary to establish the sanctity of the park even though the State Highway Department has on occasion expressed an interest in taking some of the park for a road.

For another instance of a dedicated park saved from development by restrictions as to use written into the dedication, see the cases dealing with Grant Park in Chicago: South Park Comm'ers v. Montgomery Ward \& Co., 248 III. 299, 93 N.E. 910 (1910); Ward v. Field Museum, 241 Ill. 496, 89 N.E. 731 (1909); Bliss v. Ward, 198 Ill. 104, 64 N.E. 705 (1902); Chicago v. Ward, 169 Ill. 392, 48 N.E. 927 (1897).

67 See text at notes $78-90$ infra.

68 Bi-County Open Space Planning, supta note 1, at 65.

69 Md. Code ANN. art. 66C, § 357A(a) (Supp. 1968); Laws of Md., ch. $780 § 30$ (1959), amending Montgomery County Code and Code of Public local Laws of Prince GEORGE's COUNTY.

70 Mo. Code Ann. art. 81, § 12E(a), (c), (d), (g) (Supp. 1968). 
activity. ${ }^{71}$ Other restrictions on land use may be added by covenants on specific parcels of land. No scenic easements have been donated to date in Prince George's County, probably because the program has received little publicity and because the tax savings are insufficient to prompt landowners to act on their own initiative. ${ }^{72}$ Montgomery County has failed to pass a similar proposed ordinance. ${ }^{73}$

Scenic easements as an open space preservation tool are still in the experimental stage; no one is yet certain of their utility. In the Bi-county region, scenic easements have not been acquired on a large scale for several reasons. First, Commission policy favors acquisition of the fee simple, which is generally little more expensive than easements. ${ }^{74}$ Because of the high use value of urban land only seven acres of scenic easements have been purchased in the Bi-county region. ${ }^{75}$

71 Prince George's County Scenic Easement Ordinance, General Resolution No. 1, 1966.

72 It was hoped that the added incentive of greater tax credits under the Montgomery County ordinance would change this. However, the Montgomery County Council has refused to act until it knows the approximate cost (in terms of lost tax revenues) of a scenic easement tax credit program, and so far the Commission has been unable to supply the necessary estimates. Of course, the presence or absence of a tax credit ordinance would not interfere with the Commission's ability to purchase scenic easements.

73 Montgomery County's proposed ordinance imposes restrictions on land use identical to the Prince George's ordinance, but differs from it by granting tax credits ranging from $50 \%$ to $100 \%$, depending upon the category of open space to be preserved. Thus, scenic easements on land meeting basic requirements (at least five acres, no buildings) receives a 50\% credit; low density land abutting parks or conservation areas or within designated parks or conservation areas receives a $75 \%$ credit; while undeveloped land abutting parks or conservation areas, land within designated parks or conservation areas, land selling subject to a purchase option and easements on large undeveloped tracts (at least 25 acres) receives a tax credit of $100 \%$.

74 Interview with Joseph Downs, Principal Park Planner of the Maryland-National Capital Park and Planning Commission, in Silver Spring, Md., January 2, 1969.

A 1965 Wisconsin Law Review article reports that in 1961 Wisconsin initiated a ten year, fifty million dollar outdoor recreation and resource development program which earmarked two million dollars for the acquisition of approximately 3,000 miles of highway scenic easements. Through the spring of 1965 , the program had accounted for only 108 miles of scenic easements. The author concluded that the lag in such purchases was due to the lack of expertise of purchasing agents, who were accustomed to negotiating for the fee simple, and the unwillingness of landowners to sell an easement because of their uncertainty as to exactly what interest in the land they were giving up. The cost per acre of easements $(\$ 60.89)$ was not stated to be a reason for the limited number of purchases. No figures were given for the market value of the land, making it impossible to determine the relative costs of easements and fee simples. Note, Progress and Problems in Wisconsin's Scenic and Conservation Easement Program, 1965 WIs. L. REV. 352 (1965).

75 In most areas of the Bi-county region the high value of development rights causes the price of scenic easements to approach that of the fee, making the latter a bad investment. Interview with Joseph Downs, Principal Park Planner of the Maryland-National Capital Park and Planning Commission, in Silver Spring, Md., January 2, 1969. 
Second, Maryland state law and the Bi-county ordinances require that easements be in perpetuity to qualify for a tax credit; probably few people desire to restrict the use of land by their heirs or to encumber the land with development restrictions that may make it less marketable. Yet legislative attempts to allow easements of less than perpetual duration to qualify for tax credits should be rebuffed. ${ }^{76}$ In order to preserve for all generations scenic open spaces, the Commission must solicit donations in perpetuity. In addition, it is likely that the shorter the period allowing a donation to qualify for a tax credit, the greater the chance will be that speculators might try to take advantage of the tax break by holding the land with a scenic easement donation for the minimum period while waiting for the best opportunity to develop.

Third, the existence of the preferential farmland tax assessment in Maryland decreases the chance that a person would want to donate his land. There is no reason for anyone with open space farmland to relinquish his development rights in perpetuity in exchange for a tax credit of perhaps no more than fifty per cent when he now receives a total tax abatement as long as he keeps his land in farm use. To encourage donations of scenic easements, the preferential farmland tax assessment should be abolished. ${ }^{77}$

As with donation of the fee, encouraging donation of scenic easements is a matter of public relations and publicity. To this end the Commission plans to undertake a press campaign to instruct the public in the aesthetic, conservational, and financial advantages of scenic easement donations.

5. Dedications in Subdivisions. ${ }^{78}$ Montgomery County, but not

76 House Bills 68 and 362 failed to pass the 1968 Maryland General Assembly. The sponsors of the Bills hoped to encourage donations by giving landowners an "experimental" 5 year period to see if the scenic easement program was workable. It should be noted that granting a tax credit for less than perpetual donations will make long range planning difficult since the Commission will not know how long easements will continue.

77 See text at notes $92-95$ infra.

78 The best discussion of subdivision controls, detailing Michigan's experience, is Cunningham, Public Control of Land Subdivision in Michigan: Description and Critique, 66 Mich. L. REv. 3 (1967). For a discussion of general legal problems in subdivision regulations, see Heyman and Gilhool, The Constitutionality of Imposing Increased Community Costs on New Subdivision Residents Through Subdivision Exactions, 73 YaLE L.J. 1119 (1964); Note, Land Subdivision Regulation: Its Effects and Constitutionality, 41 ST. John's L. Rev. 374 (1967); Reps and Smith, Control of Urban Land Subdivision, 14 SYRACUSE L. REv. 405 (1963). For case studies on the use of subdivision regulations to preserve open spaces, see Comment, An Analysis of Demands for Open Spaces in Maryland Subdivision Regulations, 25 MD. L. REv. 148 (1965); Volpert, Creation and Maintenance of Open Spaces in Subdivisions: Another Approach, 12 U.C.L.A.L. REv. 830 (1965); Comment, Control of Urban Sprawl or Securing Open Space: Regulation by Condemnation or by Ordinance?, 50 CALIF. L. REV. 483 (1962). 
Prince George's, has enacted subdivision regulations in accordance with a statutory provision that these two counties "may provide for ... adequate open spaces for . . . recreation ... . by dedication."79 This ordinance allows the Montgomery County Planning Board ${ }^{80}$ to require that a developer devote a portion of his land to use as a park. ${ }^{81}$ Because the developer has created the need for increased park facilities by his building activity, it seems equitable that he should pay for these increased costs. ${ }^{82}$ While the Montgomery County ordinance has not been challenged, park dedication statutes in other jurisdictions have been upheld when the court has found that "the municipality will be required to provide more land for schools, parks, and playgrounds as a result of approval of the subdivision."83

79 Laws of Md., ch. 815 (1963) amending Montgomery County Code and Code of Public Local Laws of Prince George's County. Some states, such as Maryland, Md. CODE ANN. art. 66B, $\S 26$ (1957), have less specific enabling acts which state only that park commissions "may provide" for open space for recreation with no express authority to require dedications. Whether such power is nevertheless to be implied has been a source of debate. The preferable interpretation is that since the statute nowhere specifically prohibits the use of compulsory dedications to provide for open spaces, this power might validly be read into the statute.

On the other hand, one could argue that the statute gives park commissions power to provide for open spaces by regulating the use of subdivided land but not by requiring dedications. A recent note-Comment, An Analysis of Demands for Open Space, 25 MD. L. REv. 148, 153 (1965) suggests that such vague language will not support required dedications because park commissions are specifically granted only the power to purchase or condemn parkland. A Michigan land-use authority agrees that the language probably would not support mandatory dedications but would support reservation of land for parks. Public Control of Land Subdivision in Michigan: Description and Critique, 66 MICH. L. REv. 3, 32 (1967).

The Commission has the power to reserve portions of subdivisions for park purposes by prohibiting construction on those portions until it purchases the land. The Commission is empowered to reserve land for parks for up to three years, or longer with the owner's consent (Laws of Md., ch. 815 (1963), amending MONTGOMERY COUNTY CODE and Code of Public local Laws of Prince George's County). A three-year reservation is probably an unconstitutional taking in light of the decision in Miller v. City of Beaver Falls, $368 \mathrm{~Pa}$. 189, 82 A.2d 34 (1951), where the court held that a three-year reservation of a developer's land for a public park was a taking of property without just compensation.

80 The Montgomery County Planning Board is composed of the five Montgomery County Commissioners on the Commission. See text at note 10 supra.

81 The [Montgomery County Planning] Board shall require platting and dedication to public use of adequate open spaces for recreation wherever it is reasonable to do so in view of its studies and investigations and in consideration of the circumstances within that portion of the district where such subdivision is located, taking into account also the size and character of such subdivision.

Subdivision REgulations FOR THE MARYLAND-WASHINGTON REgIONAL DISTRICT WITHIN Montgomery County, Mariland-National Capital Park and Planning Commission, $\$ 104-19$ (b) (1968). A proposed change in the ordinance would add a table of minimum acreage dedication requirements.

82 Of course, the developer can shift his increased costs onto the new residents who will make use of new park facilities. Heyman and Gilhool, supra note 78, at 1121.

83 Jordan v. Village of Menomonee Falls, 28 Wis. 2d 608, 618, 137 N.W.2d 442, 448 
Required dedications in Montgomery County have accounted for several local parks. It can be expected that the number of dedicated parks will keep pace with spreading communities. To assure that they will, Prince George's County should also provide for compulsory dedication.

Unfortunately, subdivision dedications will not always provide usable open space. For one thing, if a subdivision is small, its dedicated park will also be. There may be no room for a baseball field, tennis courts, hiking trails, or other active recreational uses. In municipalities where there is not an extensive recreation program already in operation, small dedicated parks will be inadequate.

Second, dedications of small parks would create maintenance expenses, which, because of the large number of small acreage parks, would make upkeep of the park system a drain on acquisition and development resources. ${ }^{84}$

For these reasons, Montgomery and Prince George's County "may provide for ... . the payment of a monetary fee, in lieu of dedication, not to exceed five percent $(5 \%)$ of the total assessed value of the land to be used by the Commission to purchase such open spaces for the use and benefit of the subdivision in cases where dedication would be impractical." 85

The Commission has proposed similar fee in lieu of dedication ordinances, as yet unenacted, to the Montgomery and Prince George's County governments. The proposed Montgomery County ordinance states that "said fees in lieu of dedication shall be used by the Commission to purchase open space in the immediate neighborhood to be used as recreation facilities for the use and benefit of the subdivisions ... ."86 This language is in accord with a recent court decision

(1965) (rehearing denied 1966) (dedication not an unconstitutional taking of property). See also Billings Properties, Inc. v. Yellowstone County, 144 Mont. 25, 394 P.2d 182 (1964) (dedication statute not an unconstitutional delegation of power); Jenad, Inc. v. Village of Scarsdale, 18 N.Y.2d 78, 218 N.E.2d 673, 271 N.Y.S.2d 955 (1966) (dedication not an unconstitutional tax or taking of property). Contra, Pioneer Trust and Savings Bank v. Village of Mount Prospect, 22 Ill. 2d 375, 176 N.E.2d 799 (196I) (dedication ordinance invalid as a taking without just compensation).

84 Maryland-National Gapital. Park and Planning Comm., Oren Space Dedications IN Subdrvisions 11 (Nov. 1968) (unpublished report).

85 Laws of Md., ch. 626 (1968), amending MONTGOMERY County CODE and CODE of Public Local Laws of Prince George's County.

86 Proposed Montgomery County Ordinance to amend Montgomery County Code § 104-19(b) (1965). The proposed ordinance further provides

The [Montgomery County Planning] Board may deem a dedication of open space for recreation purposes to be impractical for any one or more of the following reasons:

(i) Because of the size, shape, topography, drainage or other physical features of the subdivision the dedication would work an undue hardship on the subdivision plan or the inhabitants of the subdivision. 
holding that a fee in lieu of dedication violates the developer's right to the equal protection of the law unless the fee in lieu is used for park purposes which directly benefit the residents of the subdivision. ${ }^{87}$

The direct benefit test would seem to be appropriate except in the case in which the Commission finds dedication "impractical" because existing parks adequately serve the subdivision. In fact, it may be argued that since the Commission has already provided for the needs of the subdivision, the developer should recompense the Commission for its fair share of the cost of establishing parks. The Commission has discussed that such fees in lieu should be paid into a revolving fund to be used to purchase parks in unsubdivided areas, later to be regained in the form of other fees in lieu when those areas are developed..$^{88}$

But a Commission study ${ }^{89}$ suggests that constitutional problems might arise if the Planning Board demanded a fee in lieu in such situations. It would seem to be inequitable to remove entirely the obligation on the developer to provide recreational open space merely because of the location of his subdivision near existing parks. Yet the imposition of such a requirement would impose a double burden on the developer. In addition to the fee in lieu, he would pay a premium for the land because of the nearby park facilities. That

(ii) The open space to be dedicated is unsuitable for public use because of size, shape, topography, drainage or other physical features.

(iii) Adequate public land for recreation is readily available and accessible.

(iv) Any other such related causes.

87 Gulest Associates, Inc. v. Town of Newburgh, 25 Misc.2d 1004, 209 N.Y.S.2d 729 (Sup. Ct. 1960), aff'd, 15 App. Div. 2d 815, 225 N.Y.S.2d 538 (1962), questioned in 18 N.Y.2d 78, 218 N.E.2d 673, 271 N.Y.S.2d 955 (1966) (fee in lieu invalid because not limited to park use). But see Coronado Dev. Co. v. City of McPherson, 189 Kan. 174, 368 P.2d 51 (1962); Rosen v. Village of Downers Grove, 19 III. 2d 448, 167 N.E.2d 230 (1960) (fee in lieu of dedication requirement held bejond the scope of the enabling act); Haugen v. Gleason, 226 Ore. 99, 359 P.2d 108 (1961) (fee in lieu void as a tax which was not necessarily used for the benefit of those taxed); Kelber v. City of Upland, 155 Cal. App. 2d 631, 318 P.2d 561 (1957) (ordinances requiring a fee in lieu of dedication for park and school sites held not to be local ordinances regulating the design and improvement of a subdivision as authorized by the Subdivision Map Act). Fee in lieu requirements have recently been upheld on the grounds that they are justified for the same reasons as dedication exactions, and they are neither an unconstitutional taking without just compensation nor an unconstitutional tax. See Jordan v. Village of Menomonee Falls, 28 Wis. 2d 608, 137 N.W.2d 442 (1965); Jenad, Inc. v. Village of Scarsdale, 18 N.Y.2d 78, 218 N.E.2d 673, 271 N.Y.S.2d 955 (1966). Contra, Aunt Hack Ridge Estates v. Planning Comm'n of the Town of Danbury, 27 Conn. Sup. 74, 230 A.2d 45 (1967).

$\$ 8$ If subdivision development does not follow where the revolving fund purchase was made, the Commission could still recoup its expenses by selling what would then be unneeded parkland, or could hold it for the future.

80 Open Space Dedications in Subdivisions, supra note 84, at 20. 
this premium would benefit a third party rather than the Commission, of course, would not mitigate the unjust burden on him..$^{00}$

From this discussion, dedication and fee in lieu requirements appear to be both equitable and useful in preserving recreational open space. It seems only fair to place the burden of satisfying additional community park needs on those who have created those needs, so long as this is not an unreasonable burden and so long as those who put up money for a park will benefit from its creation. Further, subdivision dedications also provide a method of preserving open land within new communities which insures that increased park facilities will keep pace with increased park needs created by new communities.

\section{Further REcommendations}

To improve the Commission's ability to acquire and preserve open spaces, two state statutes should be amended. These recommended changes look to legislation which guarantees the permanence of increasing amounts of open space land ${ }^{91}$ while at the same time allowing flexibility in selecting lands already acquired for park purposes which may be shifted to other uses.

First, the preferential farmland tax assessment ${ }^{92}$ should be changed to provide a deferment rather than an abatement of taxes. ${ }^{93}$ Assessment at full value should be avoided, since this would place a prohibitive tax burden on the farmer, forcing him to develop the land or sell to a developer and thereby speeding the dissipation of open spaces. Substitution of a tax deferment for the present tax abatement would have three effects on open space acquisition: (I) the resulting increase in tax revenue, in deferred taxes later collected, would provide more funds for park purposes; (2) the removal of the preferential tax treatment for temporary retention of land in agricultural uses would enhance the attractiveness of tax credits for donation of perpetual scenic easements; 94 and (3) the requirement that the farmer pay

90 One way for the county to pay for a portion of each new park while avoiding the double burden on the developer is to levy a special assessment tax on the owners of land surrounding a public park at the time the park is created. The original owner will not be unfairly burdened by this tax because he will receive the beneficial enjoyment of the nearby park, or else he will recoup his tax payment when he sells the land to a developer.

01 Both federal (Housing Act of 1961, tit. VII, $\S \S 702,705,42$ U.S.C. $\S 1500$ (a)) and state open space laws (VA. Code ANN. \& 10-152 (Supp. 1968)) provide that property acquired under the Act shall be for permanent open space land.

92 Mo. Code ANN. art. 81, § 19 (Supp. 1968).

93 For a general bibliography on open space taxation methods and problems, see U.S. Dep't of Housing and Urban Dev., Open Space Land Planning and Taxation, A SELECTEd BrblograpHy (1967).

04 Pringe George's County Scenic Easement Tax Credit Ordinance, supra note 71. 
deferred taxes upon a shift from farm uses would discourage development. ${ }^{95}$

Second, limitations should be placed on the Commission's right to convey parkland. Under the current law,

The Commission is authorized to sell, convey, transfer, lease, or exchange any land held by it under this subheading and deemed by the Commission not to be needed for park purposes or other purposes of this subheading. ${ }^{96}$

When the Commission transfers land to another agency ${ }^{97}$ of the state, it must apply the proceeds from the transfer to an acquisition fund to purchase new parklands. ${ }^{98}$ However, there is no similar requirement regarding the proceeds from the sale of parklands other than the Commission's budgetary procedures.

Without greater limitations on conveyancing, there is no guarantee that open spaces will not continue to shrink even after they are bought by a public body and earmarked for public recreational use. Parkland may be in demand for private development. To make certain that the Commission does not needlessly dispose of parkland, the statute should be amended to provide that land may be sold by the Commission only when its park use no longer complies with the comprehensive plan in effect for that area. Further, the law should provide that the proceeds from such sales must be applied to other park purchases.

\section{CONCLUSion}

Because land law is local law, legal methods of open space acquisition available to local agencies will vary from jurisdiction to jurisdiction. The problem of shrinking urban open spaces is sufficiently general, however, that others can learn from the Commission's techniques. Whether or not specific recommendations in this comment are found suitable for other areas, one recommendation has nationwide applicability. If we are to save open space land for the future,

\footnotetext{
95 A ceiling should be placed on the amount of deferred taxes to prevent them from accumulating to an extent that they consume the farmer's profits from the sale of his land. This could be accomplished either by requiring payment only of the taxes that have been defexred over a 3 or 4 year period, or by requiring payment of all past deferred taxes but only up to a percentage of the sale price. Without such a ceiling, there would again be pressure on the farmer to develop or to sell before deferred taxes mounted prohibitively high.

96 Laws of Md., ch. 780, § 36 (1959) amending Montgomery COunTY CODE and CODE of Public local laws of Prince George's County.

97 See text at notes $46-47$ supra.

98 Laws of Md., ch. 780, § 61(c) (1959) amending Montgomery County CODE and Code of Public local Laws of Prince George's County.
} 
acquisition appears to offer greater assurance of permanence than regulatory restrictions.

While acquisition by purchase is usually the costliest of all preservation techniques, it is superior to preservation of open space land by regulatory measures such as zoning or by tax preferences. Neither method of regulation, in whatever form it may be proposed, guarantees the permanence, complete control, public use, and public access to open space lands which acquisition does. ${ }^{99}$ Preferential tax assessment of farmland has not stemmed the tide of speculation in the Bi-county region, ${ }^{100}$ but rather has created a gaping tax loophole which might one day lead to a development deluge. Zoning regulations providing for open spaces have proved to be too susceptible to political change and, like tax preferences, offer no guarantee that land will remain open permanently. ${ }^{101}$ The greatest advantage of acquisition is this potential for open space permanence. Despite the problem that even land owned in fee may occasionally be lost to private utilties or other government agencies, the Commission should continue to emphasize acquisition over restriction of land use, while recognizing that there also exists a need for regulatory measures to supplement acquisition where feasible.

Regulation, rather than acquisition, is emphasized today because of the flexibility it gives to planners. To be sure, it costs little to regulate land use, and much to purchase land; a park and planning commission can regulate all of the land within its jurisdiction but can purchase only limited amounts. These are distinct advantages. This study has shown, however, that there can also be flexibility in acquisition techniques. Commission planners have a wide choice in the kinds of park programs they may initiate because of the many methods by which the park purchasers may acquire land-from condemnation to negotiated purchase to subdivision exaction. If planners in other jurisdictions are more restricted because of restraints on the purchasers' legal prerogatives, the best solution would be to expand the planners' choices by expanding the purchasers' powers. Such powers should include a wide variety of techniques for acquiring fee and lesser interests in land, by negotiation and, where appropriate, by compulsion. ${ }^{102}$

99 BI-County Open Space Planning, supra note 1 , at 61.

100 See text at note 20 supra.

101 See supra note 6.

102 After this comment went to press, the 1969 Maryland General Assembly acted (I) to change the farmland tax assessment in accord with the suggestion in the text, and (2) to allow easements of less than perpetual duration to qualify for a tax credit. 